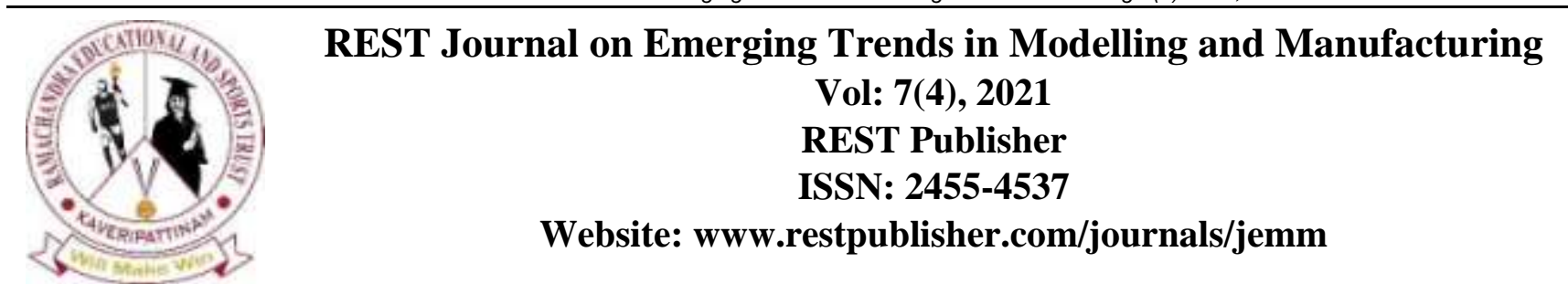

\title{
Ready to Payments Bank after Demonetisaton: An exploratory Research on Adoption of India Post Payments Bank among Postal Banking Customers in Kollam-Kerala.
}

\author{
Dr. Ratheesh. K. Nair \\ Assistant Professor of Commerce, Govt.College Kalpetta Wayanad, Kerala \\ Email: ratheeshknairkollam@gmail.com
}

\begin{abstract}
Introduction
The demonetisation of Rs.500 and Rs.1,000 currency notes(specified bank notes -SBN) from November 8, 2016 (86\% of the currency in circulation), has been one of the most significant monetary decisions taken by any Indian government. There are several dimensions of this decision such as slowdown of the economy, liquidity crunch and hardships, greater transparency and shift from cash to digital economy, reduction in black money and corruption, counterfeit currency or fake notes, countering terror funding and so on. It is important for the industry to realize and accept that every single business is moving towards digitisation. Retail sales are moving to companies like Amazon and Flipkart, travel bookings are moving to companies like Makemytrip and Airbnb, movie ticket bookings are moving to Book my show, and taxi usage is moving to Ola, Uber and so on. Here demonetisation accelerated the process of digitisation. The digital payment/receipt capability such as debit card/credit card swipe machines, e-payment wallets like Paytm and e-banking facility, and Unified Payment Interface (UPI) payment system. This research provides a connected study of two broad areas of readiness with respect to Payments bank especially for the Postal Banking customers - (1) electronic readiness of the Postal Banking customers for adoption of Payments Bank and (2) Payments Bank implementation and adoption by the banking sector in India. The analysis of sample data consisting of Postal Banking customers in Kollam district,Kerala, indicates that the Indians are reluctant in the adoption of e-payments and hence payments bank. Cash culture is still prevalent in India compared to the plastic money replacement that has been adopted in most of the developed countries. The most important reasons are lack of trust, non-availability of infrastructure, security and service charges. Approximately $23 \%$ consumers use a form of preliminary products of e-banking and are willing to have more products, services and transactions through this medium. It's the fastest and easiest way of banking yet it is not so popular among the consumers. Several organisations had been asked about strategic, operational, and technological and customer relationship issues regarding payments bank. Today, banks have welcomed wireless and mobile technology into their boardroom to offer their customers the freedom to pay bills, planning payments while stuck in traffic jams, to receive updates on the various marketing efforts while present at a party to provide more personal and intimate relationships. Payments banks are expected to adopt digital strategies to acquire new customers and operate efficiently.The study indicates a strong potential for Payments banks in India. Results highlight that payments banks will be the means to provide competitive advantage to the banks in today's hypercompetitive world. It will be a cost cutting measure to improve on efficiency to build up customer loyalty and satisfaction, and hence profitability of the bank in the long run.
\end{abstract}

\section{Statement of the Problem}

In India, the payment and settlement systems are regulated by the Payment and Settlement Systems Act, 2007 (PSS Act) which was legislated in December 2007. The PSS Act as well as the Payment and Settlement System Regulations, 2008 framed thereunder came into effect from August 12, 2008. In terms of Section 4 of the PSS Act, no person other than the Reserve Bank of India (RBI) can commence or operate a payment system in India unless authorised by RBI. Reserve Bank has since authorised payment system operators of pre-paid payment instrumentscard schemes, cross-border in-bound money transfers, Automated Teller Machine (ATM) networks and centralised clearing arrangements.Oversight of the payment and settlement systems is a central bank function whereby the objectives of safety and efficiency are promoted by monitoring existing and planned systems, assessing them against these objectives and, where necessary, inducing change. By overseeing payment and settlement systems, central banks help to maintain systemic stability and reduce systemic risk, and to maintain public confidence in payment and settlement systems. Payments banks are expected to revolutionise financial services the way e-commerce has transformed the retail industry, through service and price differentiation, refreshing approach, choice to the customer, focus on volumes over margins, and more importantly, deconstruction of established paradigms. With 11 new licences in the payments bank category, and with more to follow in the small finance bank division, these new banks need to be hailed as 'challenger banks', as they take on traditional banks with payment and settlement systems in India. The Department of Posts' plan to set up a payments bank has come one step closer to reality 
with The India Post Payments Bank Ltd (IPPB). The Department of Posts is expected to complete the rollout of its branches all over the country by September 2017.This study examines the required prospective features for theadoption of India Post Payments Bankamong Postal Banking customers in Kollami.e.,consumer adoption and confidence of the new Post Payments Bank as Payments Bank and the factors influencing the adoption of Payments Bank in India.

\section{Significance of the study}

It specifies that Payments banks are banks which will offer selected services as compared to full-fledged banks. A payment bank can only receive deposits and provide remittances. It cannot carry out lending activities. This type of bank is targeted at migrant labourers, low income households, small businesses, and other unorganized sector entities to help India reach its financial inclusion targets. These banks have to use the word Payments Bank in its name which will differentiate it from other banks. It's a step to redefine banking in India. The India Post Payments Bank may leverage the Department's network, reach, and resources to make simple, low-cost, quality financial services easily accessible to customers all over the country. Policy makers of the country can grab useful insights on the problems of India Post Payments Bank from the perspective of Postal Banking customers in terms of simple, low-cost, quality financial services to customers. This may provide valid inputs forthem to draft apposite policy framework conducive for the adoption of India Post Payments Bank in the state.

\section{Objective of the Study}

This study plans to 'plug' gap of research in the acceptance of Payments Bank among the Postal Banking customers. The primary objective of this study is to: • Identify the intention for adopting Payments Bank by Postal Banking customers. • Analyse prospective features influencing the adoption and usage of Payments Bank. The personal characteristics of Postal Bank users were found to be important determinants of their adoption decisions. This finding provides the financial services industry with a better understanding of customer perceptions of Payments Bank services and helps them plan their marketing strategies and promotion approaches for Payments Bank services in the future.

\section{Research Design}

For the present research, the study is based on Exploratory Research. The major emphasis of Exploratory Research is on the discovery of ideas. Through Exploration, the researcher develops concepts more clearly, establish priorities, develop operational definitions, and improve the final research design. This research is both quantitative and qualitative. This research is based on the data collected through "Questionnaire" fromPostal Bankingcustomers in Kollam. The data have been grouped into two main categories -primary and secondary data. The secondary data have been compiled from newspaper, journals, magazines, and web links and also research papers. The primary data have been collected through an exploratory research - Questionnaire with Postal Bankingcustomers in Kollam basically Businessmen, servicemen,professionals, students etc.The data for the research is extracted from a survey conducted in Kollam, Kerala. India. A total of 100 respondents participated in thisstudy. The demographic profile of respondents in each research is shown in Table 2. The data collected through this method was used to make projections in the research.

\section{Review of Literature}

Adoption of tele-banking as well as Internet banking has received research attention in recent years. Much of the existing research in electronic banking services has adopted an organizational perspective or a distribution channel perspective . Payments Banks are "Digital Wallet or Mobile Currency" which can be used to pay utility bills, shopping, book movie tickets etc. It is similar to Pre-Paid Instrument Providers( PPI) or what existing banks offer. But here is the difference, the payments banks could be supermarket chain, mobile service provider, non-banking financial companies, post offices, agri/dairy type cooperatives etc.In India , as per the report of the Committee on Comprehensive Financial Services for Small Businesses and Low Income Households (Chairman: Dr. Nachiket Mor Director, Central Board of the Reserve Bank of India ) (2014) and as per the announcement in the Union Budget 2014-2015 ,RBI created a framework for licensing small banks and other differentiated banks. Differentiated banks serving niche interests, local area banks, payments banks etc. Consumers using these services have been focus in a large body of current research, nevertheless customers intention to adopt payments bank have remained rather uncharted territory. This paper aims at filling that gap by shedding light on the general usage of Payments bank services and in particular on influence of financial inclusion. The survey was conducted among Postal Banking customers in Kollam. The paradigm shift, from traditional branch banking to electronic banking; the newly emerged channels; rapidly increasing penetration rates of mobile phones are among other themotivators of this study. The approach employed is practical and provides insights drawn from the quantitative empirical survey. The newly emerged mobile banking services represent an innovation where both intangible service and an innovative medium of service delivery employing high technology are present. Thus, concepts of innovation and diffusion of innovation are even more intricate as technology and service aspects have an effect on the characteristics of payments bank services .Traditionally research relating to the customer adoption of innovation has tended to concentrate on socio-demographic and psychographic attributes of potential adopters. Even though these kind of personal characteristics of a consumer have found to be predictors of adoption, an increasing body of research has demonstrated that it is the perceived attributes of innovation itself rather than the personal characteristics that are the stronger predictors of the adoption decision . In the 
search to understand consumers' adoption of innovation, and where research has focused on the consumer perspective .Rogers' diffusion model, which originally dates back to 1962, has often been employed . Within financial services innovation research [ , have applied Rogers' model to Internet banking. According to Rogers (1995) the perceived innovation characteristics are supposed to provide the framework how potential adopters perceive an innovation. Research that has investigated the product characteristics of innovation has evaluating the innovation along the product characteristics that involve five constructs; relative advantage, compatibility, complexity, trialability and observability . Concept of perceived risk is often included as augmented by Bauer (1960). Particularly in banking services the perceived risk associated with the financial product itself as well as with electronic delivery channel is higher than in basic consumer goods, and hence increasing the importance of this attribute of innovation . Ensuring security and confidentiality are the fundamental prerequisites before any banking activity involving sensitive information can take place . Relative advantage, compatibility, trialability and observability are positively related to adoption of an innovation and the remaining two, complexity and perceived risk, negatively related. These innovation attributes and their influence on adoption of mobile banking and payment banking services are detailed under empirical implications.

\section{Payments Banks in India}

The Reserve Bank of India on Aug 19, 2015 decided to grant "in-principle" approval to the following 11 applicants to set up payments banks under the Guidelines for Licensing of Payments Banks issued on November 27, 2014 (Guidelines).

1. $\quad$ Aditya Birla Nuvo Limited

2. $\quad$ Airtel M Commerce Services Limited

3. Cholamandalam Distribution Services Limited

4. Department of Posts

5. $\quad$ Fino PayTech Limited

6. National Securities Depository Limited

7. $\quad$ Reliance Industries Limited

8. Shri Dilip Shantilal Shanghvi

9. Shri Vijay Shekhar Sharma

10. Tech Mahindra Limited

11. Vodafone m-pesa Limited

The "in-principle" approval granted will be valid for a period of 18 months, during which time the applicants have to comply with the requirements under the Guidelines and fulfill the other conditions as may be stipulated by the Reserve Bank. On being satisfied that the applicants have complied with the requisite conditions laid down by it as part of "inprinciple" approval, the Reserve Bank would consider granting to them a license for commencement of banking business under Section 22(1) of the Banking Regulation Act, 1949. Until a regular license is issued, the applicants cannot undertake any banking business.

\section{Department of Posts}

The Department of Posts, with its network of 1,54,939 Post Offices, is the largest postal network in the world. The beginnings of this vast postal network can be traced back to the year 1727 when the first Post Office was set up in Kolkata. Subsequently, General Post Offices (GPOs) were also set up in the then three Presidencies of Kolkata (1774), Chennai (1786) and Mumbai (1793). To bring some uniformity amongst the then Post Offices, the Indian Post Office Act of 1837 was enacted. This Act was followed by the more comprehensive Indian Post Office Act of 1854. This Act reformed the entire fabric of the postal system and its provisions granted the monopoly of carrying mail in the British territories in India to the Indian Post Office. The present postal system in India thus came into existence with the Indian Post Office Act of 1854. In the same year, Railway Mail Service was introduced as also the sea mail service from India to Great Britain and China. Thereafter, the India Post Office Act of 1898 was passed which regulated postal services in the country. The Prevention of Money Laundering Act (PMLA) 2002 came into force w.e.f. 1stJuly 2005. The Act defines money laundering as "any process or activity connected with proceeds of crimes including its concealment, possession, acquisition or use and projecting of claiming it as untainted property." The Act was amended by the prevention of Money Laundering Amendment Act, 2009 w.e.f. 1stJune, 2009. Department of Posts was brought into the ambit of this Act with this amendment wherein Section 2(1)(1) listed Department of Posts in the Government of India as a "financial institution." Financial service provided by the department includes the following. Department of Posts operates Small Savings Scheme on behalf of Ministry of Finance, Government of India. Post Office Savings Bank (POSB) has a customer base of more than 33.03 crore account holders as on 31.03.2015. Savings Bank facility is provided through a network of 1.54 lakh Post Offices across the country. ANNUAL REPORT -2015-16,Department of Posts, Ministry of Communications and Information Technology,Government of India. The Post Office Savings Bank operates Savings Accounts, Recurring Deposit (RD), Time Deposit (TD), Monthly Income Scheme (MIS), Public Provident Fund (PPF), National Savings Certificate (NSC), Kisan Vikas Patras (KVP), Senior Citizens Savings Scheme (SCSS) and Sukanya Samridhi Accounts (SSA). 
TABLE 1. Profile of Savings Bank Schemes During 2013-2014 And 2014-2015

\begin{tabular}{|c|c|c|c|c|}
\hline \multirow[t]{2}{*}{ Name of scheme } & \multicolumn{2}{|c|}{ Number of Accounts } & \multicolumn{2}{|c|}{$\begin{array}{l}\text { Outstanding balance (Rs.in } \\
\text { crore) }\end{array}$} \\
\hline & 2013-2014 & 2014-2015 & $\begin{array}{l}2013- \\
2014\end{array}$ & $\begin{array}{l}2014- \\
2015\end{array}$ \\
\hline 1. Savings Accounts & 133501670 & 165968186 & 42959.01 & 46847.59 \\
\hline 2. RD Accounts & 110599553 & 122938104 & 74150.81 & 74515.26 \\
\hline 3. TD Accounts & 14246320 & 16238903 & 40712.21 & 51755.12 \\
\hline 4. MIS Accounts & 22017179 & 21073808 & 202083.6 & 200555.35 \\
\hline 5. NSS Accounts (87 \& 92) & 331869 & 320174 & 4149.48 & 3924.3 \\
\hline 6. PPF Accounts & 2411817 & 2424984 & 46607.65 & 52747.56 \\
\hline 7. Sr. Citizens Saving Scheme (SCSS) & 1067752 & 954177 & 22491.36 & 17974.64 \\
\hline 8. Cumulative Time Deposit & 269446 & 181634 & 6.69 & 6.69 \\
\hline 9. Fixed Deposit & 516 & 516 & 24.2 & 24.2 \\
\hline 10. MGNREGA & 62689394 & 64884602 & 0 & 0 \\
\hline 11. MSY Accounts & 2000651 & 1847916 & 3.1 & 2.98 \\
\hline 12. Sukanya Samridhi Accounts & & 2486005 & & 521.69 \\
\hline 13. Total (1 to 12$)$ & 349136167 & 399319009 & 433188.1 & 448875.38 \\
\hline 14. NSC VIII & & & 75075.89 & 85597.59 \\
\hline 15. KVP & & & 106757.58 & 84844.47 \\
\hline 16. Total $(14+15)$ & & & 181833.5 & 170442.06 \\
\hline 17. Grand Total $(13+16)$ & & & 615021.6 & 619317.44 \\
\hline
\end{tabular}

Other financial service of Department of Posts includes

1.International money transfer service

2.National pension system

3.Sukanya samridhi account

4.Postal life insurance etc.

5.E-payments

\section{India Post Payments Bank}

The Department of Posts had obtained the 'in-principle approval' of RBIin Aug 19, 2015 to set upIndia Post Payments Bank( IPPB).Setting-up of the IPPB to further financial inclusion was one of the budgetary announcements during 201516. The India Post Payments Bank will leverage the Department's network, reach, and resources to make simple, low-cost, quality financial services easily accessible to customers all over the country. The Union Cabinet under the Chairmanship of Prime Minister Shri Narendra Modi has givenits approval for setting up the India Post Payments Bank (IPPB) as a Public Limited Company under the Department of Posts, with 100\% Government of India (GOI) equity,following an in-principle approval by the Reserve Bank of India earlier. IPPB will obtain banking license from the Reserve Bank of India (RBI) by March 2017 and by September 2017, its services will be available across the country through 650 payments bank branches, linked to rural post offices and alternative channels riding on modern technology including mobiles, ATMs, PoS/ m-PoS devices etc. and simple digital payments. The objectives of setting up of payments banks will be to further financial inclusion by providing (i) small savings accounts and (ii) payments/remittance services to migrant labour workforce, low income households, small businesses, other unorganised sector entities and other users.

Scope of activities:

a.Acceptance of demand deposits. Payments bank will initially be restricted to hold a maximum balance of Rs. 100,000 per individual customer.

b.Issuance of ATM/debit cards. Payments banks, however, cannot issue credit cards.

c.Payments and remittance services through various channels.

d.BC of another bank, subject to the Reserve Bank guidelines on BCs.

e.Distribution of non-risk sharing simple financial products like mutual fund units and insurance products, etc.

Deployment of funds:

a.The payments bank cannot undertake lending activities.

b. Apart from amounts maintained as Cash Reserve Ratio (CRR) with the Reserve Bank on its outside demand and time liabilities, it will be required to invest minimum 75 per cent of its "demand deposit balances" in Statutory Liquidity Ratio(SLR) eligible Government securities/treasury bills with maturity up to one year and hold maximum 25 per cent in current and time/fixed deposits with other scheduled commercial banks for operational purposes and liquidity management. Payments banks offer small savings accounts, as also remittances and mobile and net banking services, notably to migrant labour workforce, low-income households, small businesses and other unorganised sector entities. They can also accept demand deposits up to a maximum of Rs 100,000 per individual customer, issue ATM/debit cards and act 
as agents for simple financial products like mutual fund units and insurance. The payments bank will be a game-changer in rural and semi-urban areas. It will help in our larger goal of financial inclusion. All post offices, including the 1.39 lakh of the rural post offices, will be the access points for India Post Payments Bank. These post offices will be equipped with Micro-ATMs for facilitating both cash and digital transactions.More than 50 national and international banks, insurance companies, money transfer organisations are keen to tie-up with India Post Payments Bank.IPPB will start operations in March 2017 in about 50 districts and quickly scale up to cover the entire country by the end of financial year 2018-19.The India Post Payments Bank will be professionally managed and run by a chief executive, with assistance from the designated of the departments of posts services, expenditure and economic services. The payments bank will have 5,000 ATMs.Some limited banking services are not new at post offices, which have been facilitating people to open savings accounts, recurring deposits, time deposit accounts and monthly income schemes and senior citizen savings schemes.In addition, they also facilitate the opening and maintenance of provident fund accounts, and the purchase of National Savings Certificates, Kisan Vikas Patra and Sukanya Samriddhi accounts for the girl child.

\section{Prepaid payment instruments (PPI)}

PPIare methods that facilitate purchase of goods and services against the value stored on such instruments. The value stored on such instruments represents the value paid for by the holder, by cash, by debit to a bank account, or by credit card.The prepaid instruments can be issued as smart cards, magnetic stripe cards, internet accounts, online wallets, mobile accounts, mobile wallets, paper vouchers and any such instruments used to access the prepaid amount .Mobile wallet is a digital wallet that allows users to make payments through smartphones, tablets, phablets, etc., from any location at any time. Mobile wallet market in India is surging on account of growing online transactions, rising trend towards mobile banking, and ease of usage of mobile wallet applications. In 2014-15, major application areas that drove the country's mobile wallet market included money transfer, mobile recharge and bill payments, utility applications. These applications are being predominantly used by mobile wallet users based in Tier-I cities such as Delhi, Mumbai, Bengaluru and Chennai.

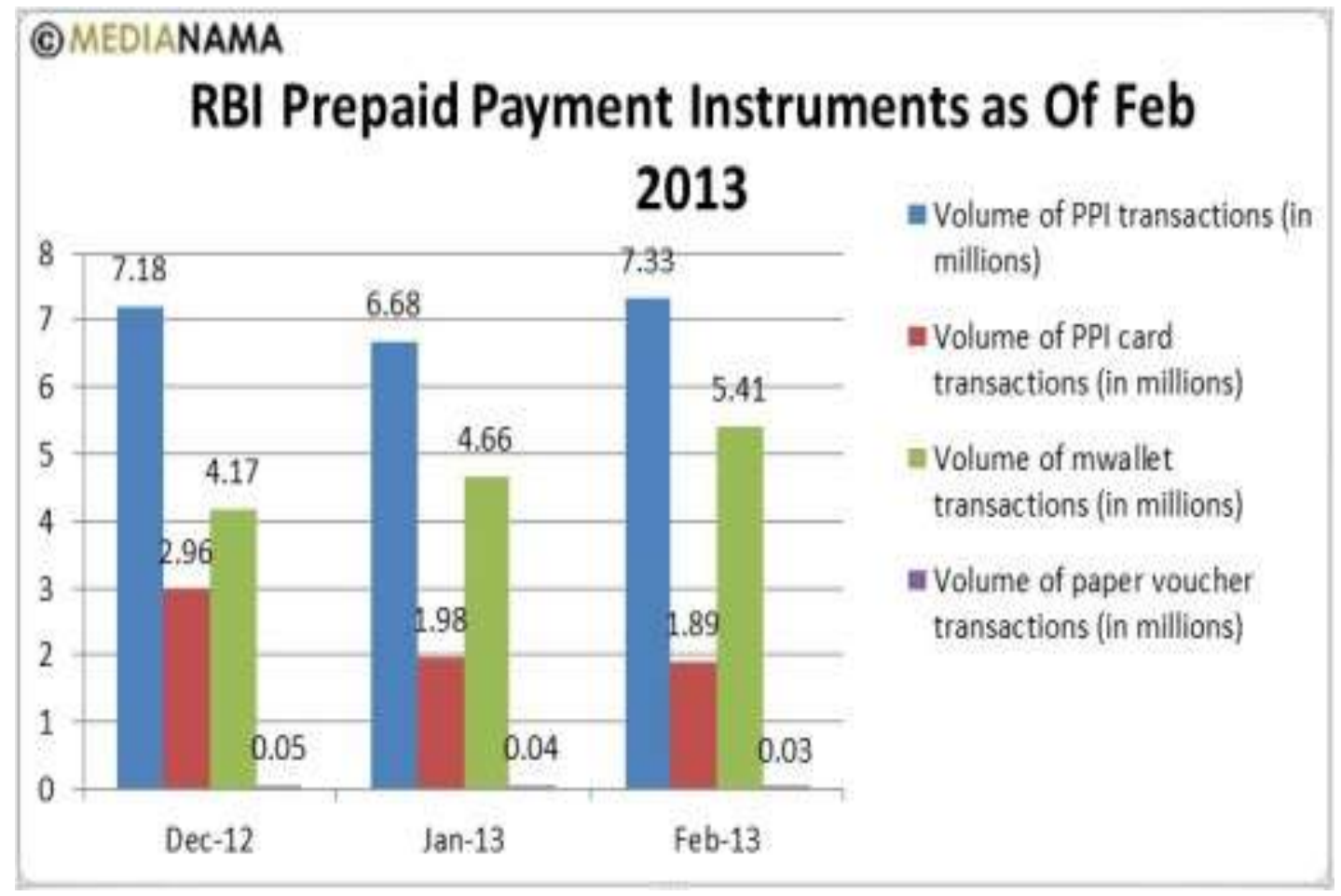

FIGURE 1. Prepaid Payment Instruments-2013

\section{Payment through M-wallet market}

In India, the usage of m-wallets (launched in 2011) has grown rapidly in recent past, and will continue to do so as customer awareness and acceptance increases. The value of transactions through m-wallet was estimated at Rs 27.5 billion last fiscal, with a majority of the transactions being remittances. Over the last two years, that number has more than tripled, although the value per transaction remains small at Rs 200-400. We estimate that the business is still not profitable, as volumes have not scaled up sufficiently to cover for the operational costs In August 2015, Reserve Bank of India approved payment bank licenses of 11 companies including Vodafone, Airtel, Paytm, etc. Consequently, the mobile wallet market in India is forecast to become highly competitive over the course of next five years. Transportation is an emerging sector in terms of using mobile wallet usage in India. Radio taxi companies such as Uber are entering into partnerships with mobile wallet companies such as Paytm to allow customers make payments through mobile wallet applications. 


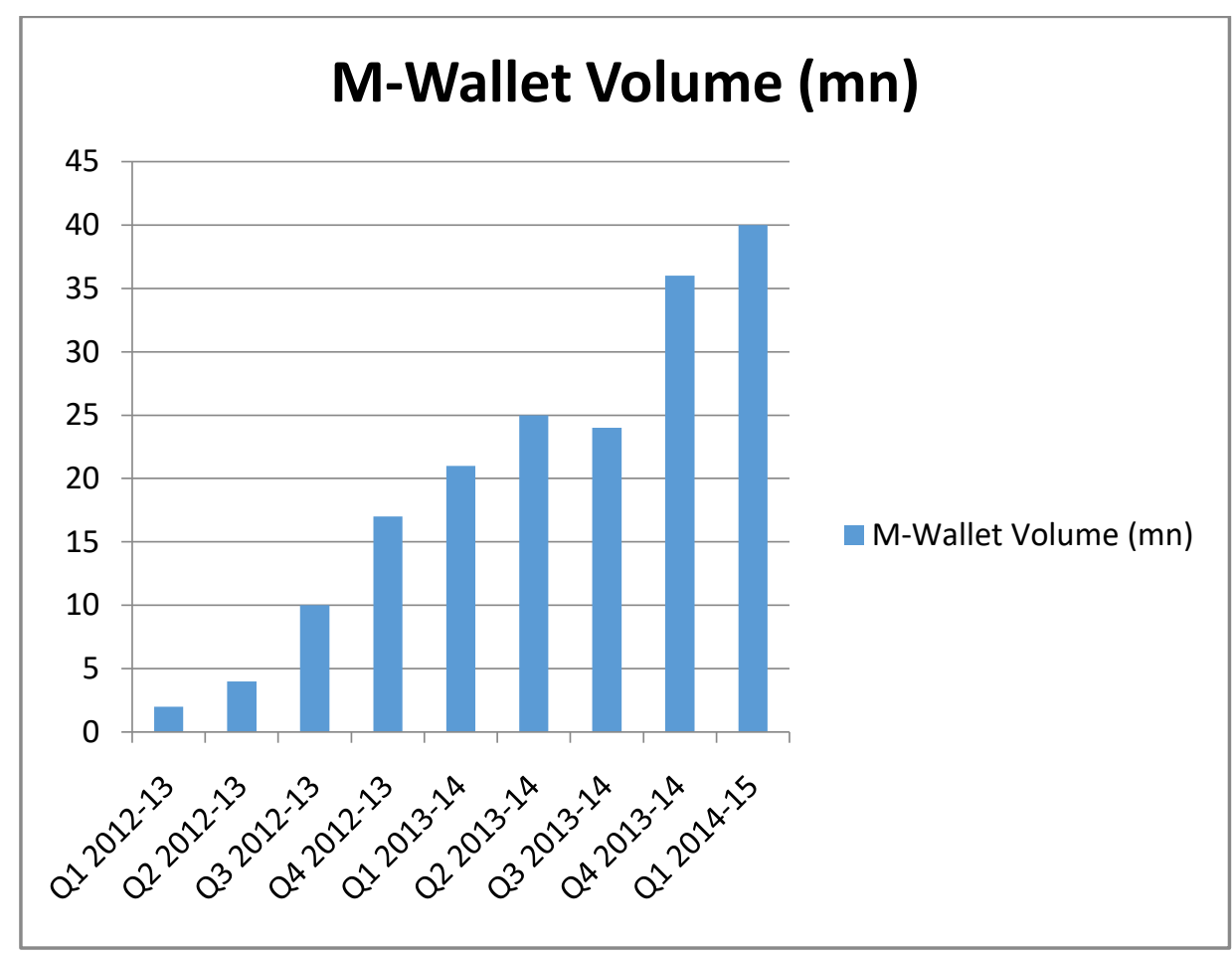

FIGURE 2. Growth in the M-wallet market

Source: Reserve Bank of India (RBI), CRISIL Research. Airtel money is an example of Pre-Paid Instrument Providers (PPI) and payment Bank(a joint venture between Airtel M-Commerce and Kotak Mahindra Bank) as on November 22,2016

\section{The "case study" of M-Pesa.}

M-Pesa is Kenya’s Payment bank. (Fundamentally, it is a Mobile payment service, just like our Airtel Money.)M=mobile; Pesa=swahili word for money.M-Pesa is the brainchild of Vodafone, Kenya's local mobile company called Safaricom and IBM. M-Pesa launched in 2006. At this time, more than 70\% of Kenya's Juntaa didnot have bank accounts.

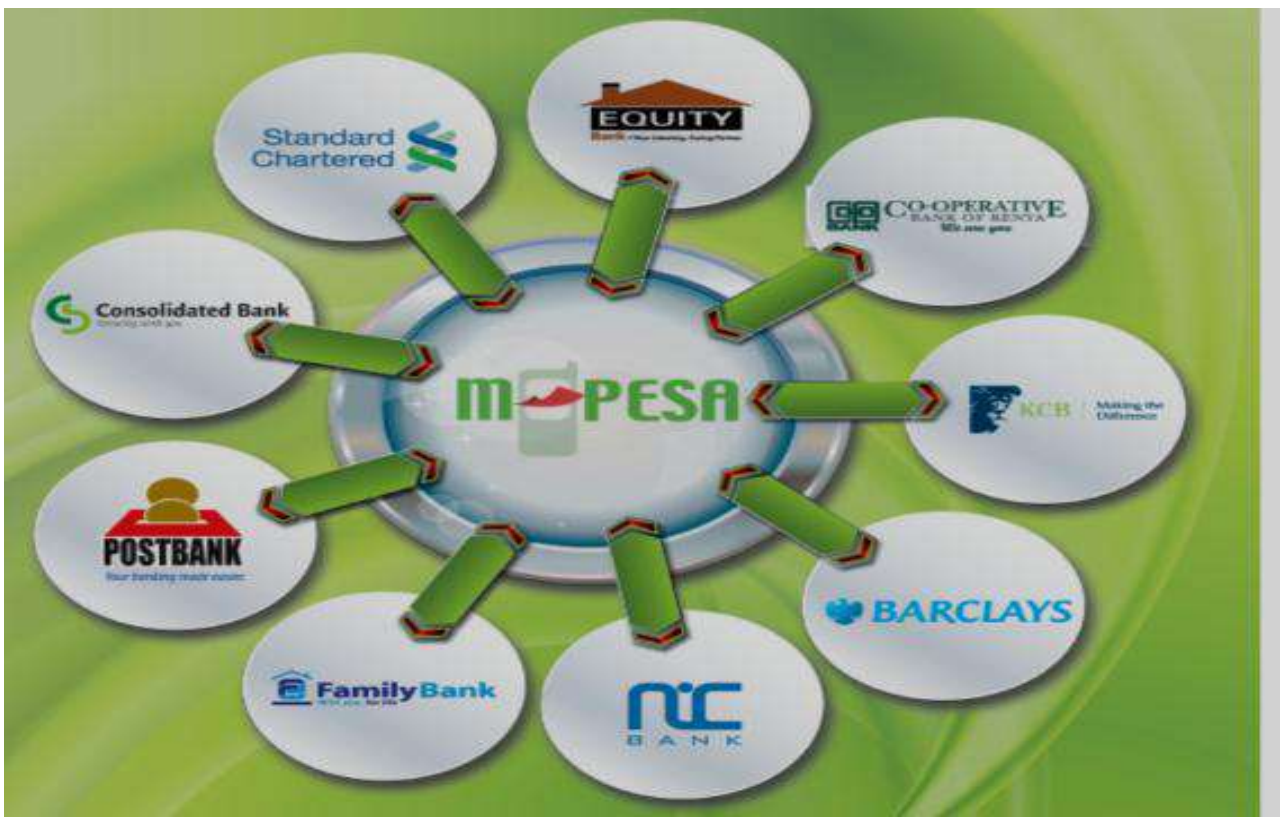

FIGURE 3. M Pesa Model in Kenya

Source :Central Bank of Kenya 


\section{How does M-pesa system Work?}

-You go to an M-Pesa outlet (local kiranawalla, shopping center, petrol pump, paan-ki-dukaan etc.)Give him cash, he fills up your M-pesa electronic account with that money. (just like how you recharge your prepaid mobile)

-This M-pesa Account is tied up with your mobile phone. Wherever you go, money goes.

-M-pesa helps in money transfer between one person to another, international remittances (e.g. Kenyan worker from USA can send money home), utility bill payments and so on.

-You can even borrow money from Microfinance Institutions (MFI) via mobile phone (and later repay the loans, via same mobile phone).

\section{M-Pesa size and Success:}

-Today, More than $75 \%$ of Kenya's juntaa uses M-Pesa system

-More than 25\% of Kenya's GDP flows through M-Pesa system.

-M-Pesa also offers a separate model called "M-Shwari" to give 2-5\% interest rate on your money saved in that M-Pesa account.

This "case study" of M-Pesa strengthen the argument in favour of Payments banks in Kenya. When businesses require collection of bills and other payments from customers across the country, the Post Office offers a simple and convenient solution in the form of e-payment. It is an option for businesses and organizations to collect their bills or other payments through the Post Office network. It is a many-to-one solution which allows collection of money (telephone bills, electricity bills, examination fee, taxes, university fee, school fee, etc.) on behalf of any organization. The collection is consolidated electronically and the payment is made centrally through a cheque from a specified Post Office of the biller's choice.

\section{Postal Banking customer behaviour-An analysis}

The adoption of India Post Payments Bank is the function of independent factors ranging from socio economic conditions to customers utilities. These factors determine the decision for the adoption of India Post Payments Bank. customers demographic profile and behavioural factors have close relation to their preference of India Post Payments Bank in Kerala. It determines the customer objectives and their choices. There is an association betweencustomergenderand perception towards India Post Payments Bank. However, customerchoices are significantly influenced by the features of India Post Payments Bank. It can also be influenced by macroeconomic factors, such as interest rates and expectations regarding inflation or recession. In this study, the adoption intention of India Post Payments Bank mainly focus on the customers attitude towards the various factors and their expectations while investing in it. This study using information from customers in Kollam deals with these aspects in a detailed manner.

\section{Profile of Sample Postal Banking customers}

The profile of the customers includes gender, age and monthly income. The profile of 100 Postal Banking customers are from Kollam regions in Kerala.

TABLE 2. Demographic Profile of Respondents

\begin{tabular}{|l|l|l|l|}
\hline \multicolumn{4}{|c|}{ Postal Banking customers Profile } \\
\hline Factor & Male & N & $\%$ \\
\hline \multirow{3}{*}{ Gender } & Female & 50 & 50 \\
\hline \multirow{4}{*}{ Age } & Up to 30 & 50 & 50 \\
\cline { 2 - 4 } & $31-40$ & 34 & 34 \\
\cline { 2 - 4 } & $41-50$ & 45 & 45 \\
\cline { 2 - 4 } & Above 50 & 17 & 17 \\
\hline Monthly Income & Up to 5000 Rupees & 4 & 4 \\
\cline { 2 - 4 } & 5001 to 15000 & 30 & 30 \\
\cline { 2 - 4 } & 15001 to 25000 & 14 & 44 \\
\cline { 2 - 4 } & Above 25000 Rupees & 12 & 12 \\
\hline
\end{tabular}

Source: Survey data. Among the sample, 46 per cent customers are male and 54 per cent customers are female. Most of the respondent's, 45 per cent has 31 to 40 age group. Monthly income of customers include High income group of 12 per cent respondents, and 58per cent medium income group and Low income customers are20.63 per cent. Postal Banking customers behaviour by customers in Kollam is analysed with demographic and customer profile which have close relation to the preference of India Post Payments Bank. Perception towards India Post Payments Bankas per the Payments Bank features defined as how the customers judge, predict, analyze and review the procedures for adoption of payments bank decision while selecting India Post Payments Bank.On the basis of this opinion, behaviour of individual customers of Kollam is analysed. Customers were asked about their intention to adopt India Post Payments Bank through indicate their requirement from the India Post Payments Bank. The study previously mentioned that the features of payment banks are 
significantly related to their demographic features which include gender, age and income. The following section at first cross tabulates the data and thereafter conducts the test of attributes using Chi square analysis.

\section{Relationship between Gender Category and intention to adopt India Post Payments Bank}

For testing the association between GenderCategory and intention to adopt India Post Payments Bank the following hypothesis were made.

H0: There is no association between GenderCategory and intention to adopt India Post Payments Bank.

H1: There is association between GenderCategory and intention to adopt India Post Payments Bank.

TABLE 3. Association between Gender Category and intention to adopt India Post Payments Bank.

\begin{tabular}{|l|l|l|}
\hline Prospective features \# & Gender \\
\cline { 2 - 3 } & Male & Female \\
\hline Personal service & $30(90.9)$ & $15(62.5)$ \\
\hline Financial Service (Insurance ,mutual fund etc.) & $28(84.8)$ & $20(83.3)$ \\
\hline Information (USSD)Pass book etc. & $30(90.9)$ & $17(70.8)$ \\
\hline Risk (Contagion,Technical etc.) & $29(87.9)$ & $20(83.3)$ \\
\hline Cash withdrawal facility (ATM) & $28(84.8)$ & $19(79.2)$ \\
\hline Govt.Schemes and service & $30(90.9)$ & $21(87.5)$ \\
\hline Payments/remittance services & $31(93.9)$ & $20(83.3)$ \\
\hline Benefits ,Interest ,discounts etc. & $28(84.8)$ & $19(79.2)$ \\
\hline Technical service (m -wallet) & $31(93.9)$ & $18(75.0)$ \\
\hline Impact of Demoetisation & $30(90.9)$ & $18(75.0)$ \\
\hline$\square$ & $\mathbf{2 0 . 1 0 7}$ & \\
\hline Sig. & $\mathbf{. 0 2 8}$ & \\
\hline
\end{tabular}

\#Multiple response

Note: Figures in parenthesis indicate per cent.

Source: Survey data

*The Chi-square statistic is significant at the five per cent level.

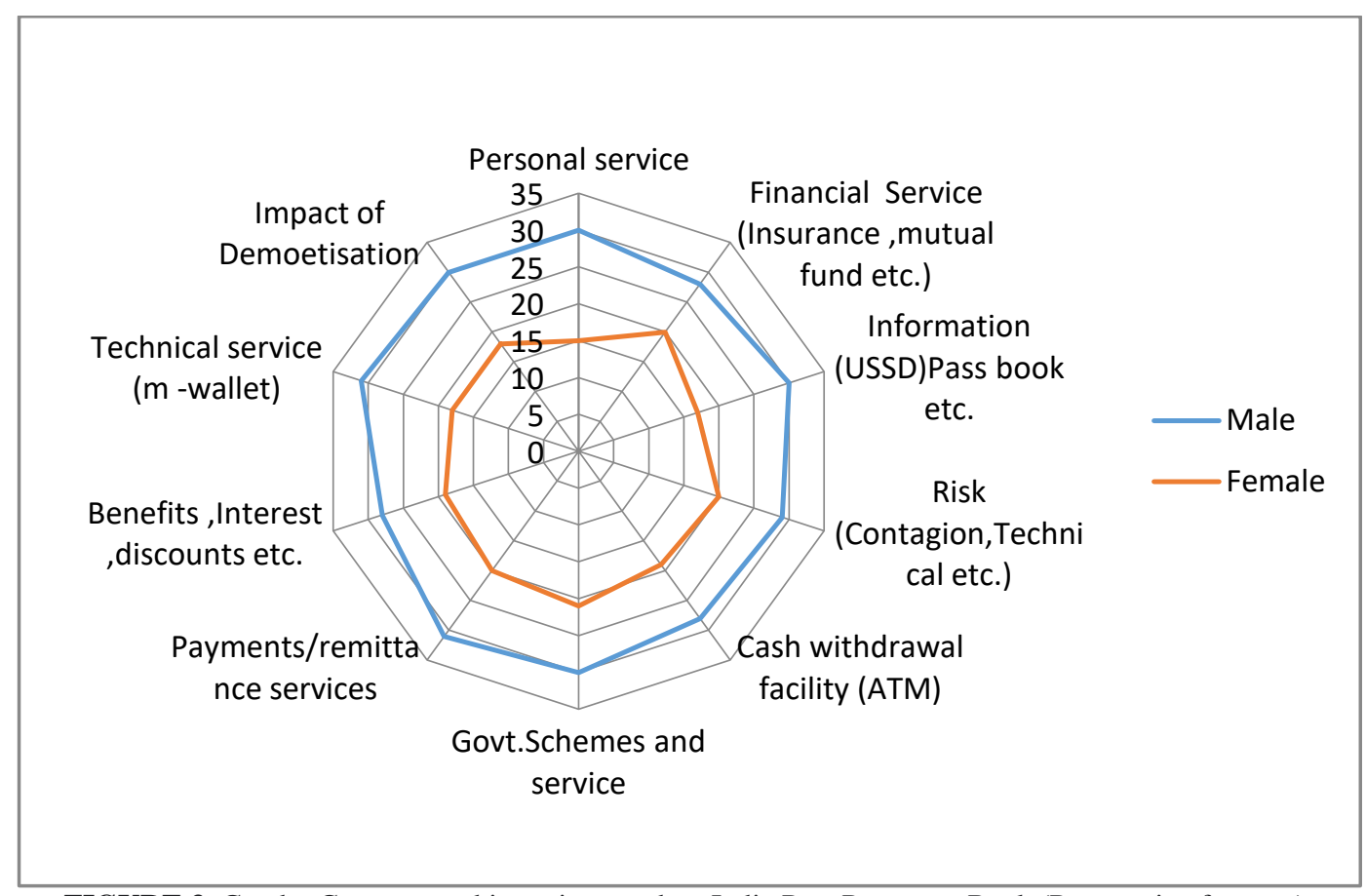

FIGURE 3. Gender Category and intention to adopt India Post Payments Bank (Prospective features)

On looking across the columns of Table 3 and Fig.3, we came to know that there is uniformity in pattern of investments by both groups. However a close observation finds divergence in the magnitude of intention by male and female. On account of this Chi square value found significant at five per cent level. Accordingly we reject the null hypothesis and can infer that the intention to adopt India Post Payments Bankbetween the two gender groupsare diverging to each other. Such difference can be due to the myopic view of customers, especially which of female group, towards the India Post Payments Bank. A well designed information efficiency seeking financial literacy program can bring significant change in this regard. 


\section{Postal Banking customers Expectations in India Post Payments Bank}

This part of analysis examines the expectation of customers regarding the various dimensions of India Post Payments Bank. The respondents provide information on five point scale about prospective features of India Post Payments Bank. The mean expectation score on each of the statements for Male and Female have been computed separately. Inferential analysis using independent sample test then employed to find out the statistical significance of the difference in expectations of both customer groups.

TABLE 4. Postal Banking customers Expectations in India Post Payments Bank.

\begin{tabular}{|c|c|c|c|c|c|}
\hline \multirow[t]{2}{*}{ Sl.No. } & \multirow{2}{*}{$\begin{array}{l}\text { Prospective features to adopt India Post } \\
\text { Payments Bank }\end{array}$} & \multicolumn{2}{|c|}{ Mean Score } & \multirow[t]{2}{*}{$\mathbf{t}$} & \multirow{2}{*}{$\begin{array}{l}\text { Sig. } \\
(2- \\
\text { tailed) }\end{array}$} \\
\hline & & Male & Female & & \\
\hline 1 & Personal service & 3.425 & 3.42 & 0.056 & 0.955 \\
\hline 2 & Financial Service (Insurance, mutual fund etc.) & 3.32 & 3.1225 & 2.086 & $0.037 * *$ \\
\hline 3 & Information (USSD)Pass book etc. & 3.4375 & 2.88 & 5.765 & $0.000 *$ \\
\hline 4 & Risk (Contagion, Technical etc.) & 2.81 & 3.19 & -3.991 & $.000 *$ \\
\hline 5 & Cash withdrawal facility (ATM) & 3.46 & 2.91 & 5.831 & $0.000 *$ \\
\hline 6 & Govt.Schemes and service & 3.4475 & 2.8275 & 6.469 & $0.000 *$ \\
\hline 7 & Payments/remittance services & 3.4575 & 2.91 & 5.808 & $0.000 *$ \\
\hline 8 & Benefits ,Interest, discounts etc. & 2.7175 & 3.0825 & -4.03 & $0.000 *$ \\
\hline 9 & Technical service (m -wallet) & 2.91 & 2.8525 & 0.575 & 0.565 \\
\hline 10 & Impact of Demoetisation & 3.415 & 2.7275 & 7.524 & $0.000 *$ \\
\hline
\end{tabular}

Impact of Demoetisation

*Significant at one per cent level

** Significant at five per cent level

Source: Survey data. The results of analysis reported in Table 4 discuss the importance of the variables involved in prospective Postal Banking customersdecision function. At first the mean expectations of male customersis considered. Among the ten variable identified the male perceive two variables at lower scale which includes Risk (Contagion, Technical etc.) and Benefits ,Interest ,discounts etc.Female perceptions on six variables are at a scale lower than that of males. Regarding the Financial Service (Insurance, mutual fund etc.),Information (USSD)Pass book etc.,Cash withdrawal facility (ATM),Govt.Schemes and service,Payments/remittance services ,Impact of Demonetisation. The statistical significance of all these findings was verified with the $t$ test procedure. The test found significant difference in perception of two customer groups regarding the eight variables .

\section{Summary findings and suggestion}

This study is exploratory in nature. The study primarily based on the survey data collected from 100 sample Postal Banking customers through a self -administered questionnaire. The qualitative variables used in the study were measured on Likert type scaling techniques. Postal Banking customers in Kollam district constitute the universe or population in this study. To study the prospective featuresinfluencing the adoption and usage of Payments Bank ,Kollam, the opinions of both Male and Female customers, are considered. Gender difference exists among Postal Banking customers towards their adoption of India Post Payments Bank. Although both group of investors mostly perceived financial services for the adoption of India post payment banks, they showed differences in their behaviour towards prospective features of payment banks. When female investors have given priority to risk and benefit features, male investors perceived it at lesser percentage and give importance to payment and other service. The study also examined the expectation of Postal Banking customers regarding the various dimensions in adoption of India Post Payments Bank. Among the ten variable identified the male perceive two variables at lower scale which includes Risk (Contagion, Technical etc.) and Benefits ,Interest ,discounts etc.Female perceptions on six variables are at a scale lower than that of males. Regarding the Financial Service (Insurance, mutual fund etc.),Information (USSD)Pass book etc.,Cash withdrawal facility (ATM),Govt.Schemes and service,Payments/remittance services ,Impact of Demoetisation. The statistical significance of all these findings was verified with the t test procedure. The test found significant difference in perception of two customer groups regarding the eight variables. India post payments are preferred by male customers due to the service provided by the payments banks.Female customers consider the risk and benefit aspect in payment banks. A well designed information efficiency seeking financial literacy program can bring significant change in this regard. However more people are interested to invest in payment banks provided their savings base is improved. India post payments bank companies should design schemes which are tailored to the customers from different earnings and service profile. Femalecustomers have lower inclination to payment banks services and they have the feeling that payment bank investments are risky. Inadequate investor protection measures and imperfect market conditions are raised as the main factors contributing risks to payments bank. Here the role of intermediaries (postal agents). is crucial ,Payment of bills and remittance of cashare remained as a problem even to postal bank customers. A good plan with customised and innovative features is highly essential for the payments bank to penetrate deep in to the market. Priorities should be given to the improvement in payment services and grievance redressal 
services rendered by payments bank, such actions definitely improve the adoption of India Post Payments Bankconditions of payment and settlement function in Kerala thereby the growth of the sector.

\section{Suggestion- India Post Payments Bank:}

* It will offer basic banking, payments of direct benefit transfers, utility bills, collection of taxes and fees, remittances.

* It will also provide easy access to loans, collect EMIs, provide insurance (life, health, accident, two-wheeler/auto, crop, etc.), pensions, investment opportunities like mutual funds, forex etc. in tie up with third party financial service providers.

* It will have a focus on rural, semi-urban, unbanked areas and among the under-banked segments of the society.

* India Post Payments Bank will usher in state of the art internet and mobile banking platforms, digital wallets, use emerging technologies such as Unified Payments Interface (UPI), e-KYC and catalyse the shift from a cash dominant to a less cash economy.

\section{Conclusion}

Innovative products with fewer risk, speed and efficient grievance redressal together with imparting professionalism in customer services definitely can find good market for India post payments bank in Kerala given the buoyant financial inclusion and cash less economic conditions of India. The India Post Payments Bank Ltd (IPPB) should understand the general investor behaviour of Keralites and must trace out the forces restraining them to be the part of the system. This shall help them to design payment schemes that has a perfect match with the customer expectations. Policy makers of the country should draft apposite policy framework conducive for the growth of IPPB in Kerala. Such initiatives at national level, at least partially, could address the developmental issues of whole nation.

\section{Reference}

1. Al-Ashban, A. A. \& Burney, M. A. 2001. Customer adoption of telebanking Technology: the case of Saudi Arabia. International Journal of Bank Marketing. Vol. 19 (5), pp. 191-200.

2. Bradley, L. \& Steward, K. 2002. A Delphi study of the drivers and inhibitors of Internet banking. International Journal of Bank Marketing.Vol. 20 (6), pp. 250-260.

3. Daniel, E. 1999. Provision of electronic banking in the UK and the Republicof Ireland. International Journal of Bank Marketing. Vol. 17 (2), pp. 72-82.

4. Black, N. J. \& Lockett, A. \& Ennew, C. \& Winklhofer, H. \& McKechnie, S.2002. Modelling consumer choice of distribution channels: an illustration from financial services. International Journal of Bank Marketing. Vol. 20(4), pp. 161-173.

5. Reserve Bank of India

6. Union Budget 2014-15

7. Thornton, Jennifer and White, Lesley (2001), "Customer Orientations andUsage of Financial Distribution Channels," Journal of Services Marketing.Vol. 15 (3), 168-185.

8. Mohr, J. 2001. Marketing of high-technology products and innovations.Upper Saddle River: Prentice Hall.

9. Howcroft, B. \& Hamilton, R. \& Hewer, P. 2002. Consumer attitude and theusage and adoption of home-banking in the United Kingdom. International Journal of Bank Marketing. Vol. 20 (3), pp. 111-121.

10. Black, N. J. \& Lockett, A. \& Winklhofer, H. \& Ennew, C. 2001. The adoption of Internet financial services: a qualitative study. International Journal of Retail and Distribution Management. Vol. 29 (8), pp. 390-398.

11. Polatoglu, V. N. \& Ekin, S. 2001. An empirical investigation of the Turkish consumers' acceptance of Internet banking services. International Journal of Bank Marketing. Vol. 19(4), pp. 156-165.

12. Source :Reserve Bank of India. Tan, M. \& Teo, T. S. H. 2000. Factors influencing the adoption of Internet banking. Journal of the Association for Information Systems. Vol. 1 (5), pp.1-42.

13. Rogers, E. M. 1995. Diffusion of innovations. 4th edition. New York: Free Press..

14. Moore, G. C. \& Benbasat, I. 1991. Development of an instrument to measure the perceptions of adopting an information technology innovation. Information Systems Research. Vol. 2 (3), pp. 192-222.

15. Bauer, R.A. 1960. Consumer behaviour as risk taking. Proceedings of the Educators Conference, American Marketing Association, pp. 389-398.

16. Howcroft, B. \& Hamilton, R. \& Hewer, P. 2002. Consumer attitude and the usage and ' ' ‘adoption of home-banking in the United Kingdom. International Journal of Bank Marketing. '”'Vol. 20 (3), pp. 111-121.

17. Jayawardhena, C. \& Foley, P. 2000. Changes in the banking sector - the case of Internet banking in the UK. Internet Research: Electronic

18. 'Guidelines for issuance and operation of Prepaid Payment Instruments in India. Reserve `Source :Reserve Bank of IndiaBank of India. Rbi.org.in. Retrieved on 29.03.2016. 